\title{
The Developement of Learning-Tools Oriented Learning Problem Based to Improve Ability Solving Problem and Self Studying of Students SMA Negeri 1 Kualuh Selatan
}

\author{
Pargaulan Siagian ${ }^{1}$, Dwi Purwanti ${ }^{2}$ and Zulamry ${ }^{3}$ \\ \{pargaulansiagian@yahoo.com \} \\ Department of Mathematics, Mathematics and Science Faculty. State University of Medan, \\ Indonesia ${ }^{1,2,3}$
}

\begin{abstract}
The objective of this study is to expose : 1) validity of learning-tools oriented learning of problem-based to develop; 2) be practical learning-tools oriented learning problem base to develop; 3) the effectiveness of learning-tools of learning oriented problem based to develop; 4) improvement capability problem solving in those students adopting a learning-tools oriented learning problem based to develop. In the study was taken that (1) the learning- tools in developed was valid to the total average of validity $\mathrm{RPP}=4.60$, students book $=4.45$, teachers' book $=4.47$. $\mathrm{LKS}=4.52$, test ability to solve problem was in valid enough and valid in reliability of 0.910 , and questionnaire in selfstudy was in valid category and valid sufficient with reliability of 0.97 ; (2 )the learningtools in development meets a practical criterion viewed from a) teachers' assessment in category easily to execute; b) students' valuation was in highly easy to conduct; and c) how to execute the learning is in the best category; 3) the learning-tools meets the an effective criterion; 4) average rise ability in solving problem on student from the test 1 through test II was 0.29 point with improvementfor full-program to study classically was $15.12 \%$
\end{abstract}

Keywords: learning-tools, model learning problem based, ability to solve problem. Selfstudying.

\section{Introduction}

Mathematics is acknowledged the queen science is at once science serving high required in dealing with global era. Mathematics constituted as an essential science as base to life forever. So, scholar with certain rate on mathematics highly required to all students for future one may get gain properly career and maintain in global era, surely not career without mathematics .

In reference with it, mathematics is one of lessons have highly important role in education, by mathematics is allowable to develop one's way of thinking critically, creative, systematic, and logical. In addition, mathematics may contribute in daily life every things in simple such as basic calculation through matters in very complex and abstract such as to apply numerical analysis in engineering and so forth. 
One of competences highly need to develop in mathematics as contained in curriculum such as aspect of solving problem. Solving problem is an important thing for one is led in endeavor to find the solution since it may present a concrete experience so by that experience may use in solving the problems alike.

It is relevant to NCTM (2010:1) program insist that the term of solving problem shall rely on the function of mathematics having highly potency to present an intellectual challenge in order to improve the development and know mathematics by students. Solving the problem is constituted a part of curriculum for the mathematics itself is highly important in process of learning and how to solve it, for the students is allowable to get many experiences in uses knowledge and basic skill to apply it for daily life dealing with problems.

Solving the problem should be an essential course in learning mathematics on school due to the student become more competent to select relevant information, then analyze it, research ever; (2) intellectual satisfactory may arise inside that seen as intrinsic problem; (3) potency intellectual of student improved; (4) student may know how to find by process and find invention (Hudojo, 2005:133).

With premises as above, it sees surely one's ability to solve problem must get special approach, since it has truly highly strategic role in develop potency to the student, particularly on mathematics.

Unfortunately, the student can not solve the problem yet properly, then it may cause the result of learning mathematics never existed as hope. According to the result research of Trends International Mathematics and Science Study (TIMSS) in 2003 that Indonesia was in 34 ranks out 45 countries. In such performance is seen more poor relative to the program for International Student Assessment (PISA) for 2003 put Indonesia on the lowest rank of 40 countries sample, meant just one level higher than Tunissia. For Indonesia attended TIMSS for 1999, 2003, 2007, and PISA in 2000, 2003, 2006, 2009 the outcome showed not any change to each joint as participant (Wardani and Rumiati, 2011:1).

Seen low ability to solve the problem as on the result of observation in early and by interview with teachers of mathematics on SMA Negeri 1 Kualuh Selatan that mostly student got difficulty in solving the problem. The result of observation also indicated mostly student is massively in learning mathematics and showed poorly response upon the learning and courses is taking place.

The research was done on $5^{\text {th }}$ September 2016, provided test of competence how to solve problem in material tri-gonometric upon 25 students Grade XI SMA Negeri 1 Kualuh Selatan, indicated to a maximum score $100,36 \%$ students got score 0 for nothing the student can answer, and they acknowledged having not know how to answer, and another $48 \%$ got score arranged $10-40,12 \%$ got score ranged 50-60 and only $4 \%$ students got score 90 . This result indicated how poorly ability to solve the problem, whereas this material they had learned in course of class-room.

That poor condition must be treated, lead the student be custom to solve the problem in class-room. The activities with taking solving the problem according to Ruseffendi (1991:341) consisted of 1) formulate the problem clearly; 2) re-telling the problem in a form that may can be solved; 3) to make hypothesis and strategy to solve, 4) set own procedure how to solve them; 5) make evaluation upon the solving. In relating with Ruseffendi, Polya (1973:5), the solution upon solving the problem contained 4 phases for solving, they are : (a) to understand the problem, (b) make own plan to solve, (c) take solution refers to own plan, (d) make review. The steps with ability to take solution upon the problems as above, for each should know them for hope by this ability, in future the student may get self-ability to solve the problem in mathematics and any problem that he may find in daily life. 
Beside ability to solve the problem, the request in Curriculum 2013 at present it not only rely on hardskill, but also soft-skill, noted one of them is willingness to self-study. The learning as designed is hope to allow each student not only to receive information and knowledge alike by explanation of teachers but they must be able to create own concept and principle. This approach is one of reality things in self-study as student.

Sumarnopointed out that self-study is a process of design and self-monitory properly upon a cognitive and affective process in solving own academic (by Purnamasari, 2014: 4). Under self-study shall encourage student start studying by own-self not depending on teachers, parent or other people. This self-study process permit students a worthy opportunity to deepen their awareness on the environment. In self-study approaching grant student to make own positive choices how a student may deal with worries and confusions in daily life. This motive allow the student may act according to own initiative to set up environment. How principle to have self-study in mathematics is due to demand in curriculum for the student can face the problem in class-room or out where they life more complex and also let them reduce dependent on other people in daily life (Fauzi, 2011:11).

Based on particulars as mentioned above, it can be concluded that self-study approach is highly required for each individual can take initiative, with or without other helping, mainly in arranging whatever activities to be done such as to formulate the purpose of studying, sources of knowledge (either as people or material), how to diagnose the requirement in study and control one-self the process of learning.

How essential self-study approach on student is not conformed with the reality yet as seen in field. Upon the questionnaire that has been presented to 20 students of Grade X SMA Negeri 1 Kualuh Selatan, then take conclusion that average self-study with 2.61 from maximum score 4. This rate is categorized poor in 2.6 rate is perhaps below 3 . By an analysis done then obtained that : (1) $40 \%$ of students not capable to evaluate the process and the performance; (2) $50 \%$ students having no initiative to study; (3) still $65 \%$ of students can not diagnose yet the need for study; (4) $80 \%$ of students can not control self yet; and (5) for another $55 \%$ student can not explore and employ the resources available to explore.

By the cases and findings in field, poorly ability to solve the problem on students are because of several factors they are : First, the plan of learning provided by teachers is not conformed with the criterion to develop the learning-tools properly. This case correlated with : (1) the learning activity under RPP is not specifically to indicate the student and teachers in activity; (2) RPP in use by teachers is still the copy of other teacher made already previously and provided in generally; (3) the steps in the learning not contained allocation of time on each process of learning; and (4) there is no any rubric of score on the assessment on the student.

Secondly, Books of learning used on SMA Negeri 1 Kualuh Selatan found with some weakness, they are : (1) the questions available not indicated the steps that may measure one's ability to solve the problem in mathematics; (2) mostly present formula immediately and then use it to solve the problem later, the book of learning contained not the steps how to find formula so mostly students only memorize that occasion forget later how to use; 3 ) the handbook that students use is not attributed to their character as student.

Thirdly, the students have no any pieces paper to make activity, so the process how to develop ability to solve the problem and how to communicate mathematics not run well. Fourthly, test ability of student contained shortage of point development of capability and self-study in student. By several factors as above, the learning-tools is the dominant factor how lower ability how to solve the problem and self-study. 
In order to enrich their ability how to solve the problem and to have self-study, it is highly required a learning-tools to support. It means, now there is a challenge to those teachers how to develop a learning-tools own refers to the Regulations No. 14 of 2005 regarding Teachers and Lecturers, pointed out that teachers competence covering a competence in pedagogic, competence in personality, competence in social and competence in professional and to attain it by profession.

Under required professional competency, so each teacher is obliged to arrange own learning-tools completely and systematically for the learning-approach can take place interactively, inspired, favorable, challenge to and motivate student to take part actively, and allow space sufficient to say initiative and creative and make own self-study according to talent, interested, and physical development as well as psychological. The learning-tools is acknowledge a tools to use in the process of learning (Trianto, 2011:201). Some learningtools as required such as RPP, syllabus, LKS, books and evaluation devices. In addition, the learning-tools is also used as reference to those students with their portion to take part effectively. Nur (in Sulistyaningsih, 2012:2) stated that the learning-tools may provide easiness and assist the teachers in preparation and also to execute the learning-studying in class-room.

How to develop all the learning-tools above mentioned, it must be relied on a model of learning for the tools available to develop become unity to equip each other and focused on the purpose to gain. There are many models of learning can be used in order to enrich their ability for soling the problem and how to get student self-study, one of the models supporting to the character of mathematics is known as learning problem based. (PBM).

PBM model is acknowledged a learning model based upon several problems requiring researching authentic namely how to know solve truly upon a reality problem (Trianto, 2011:90). The problems was adopted to link one's willingness to know, ability in analysis and initiative of students over the material of learning. This model may coach the students how to solve the problem according to their knowledge. The process itself mayframe up new knowledge be more profitable to all students.

The statement as above shall be correlated with the opinion Donalds Woods (in Amir, 2010:13) pointed out that PBM is more than large environmental effective to study and know his/her life in solving the problem, team cooperation and how to communicate. Under a selfstudy may offer freedom to the student to find how their live refers academic values. The student may take own conclusion and responsible for the points as consequences of that decision. The student also own arrange and adjust their actions to achieve the targets as want to.

Model PBM encourage students not only just thinking in concretely, but also to think ides abstract and completed. Apply PBM model can assist student become scholar. Under supervision by teachers, the learning with PBM model can encourage students to ask many questions, to complete self assignments in learning, and solve the problems that student find in daily life.

By expose to background and see weakness ability to solve the problems and self-study of the student SMA Negeri 1 Kualuh Selatan indicated that quality of learning-tools used not good as well. So, it is required development of any learning-tools highly quality and refers to the criterion fulfilling with valid value, practical and effective. One of criterions to be taken is how to achieve indicators of rising ability of solving the problem.

The result of development in learning-tools oriented PBM model is highly expected as alternative to set up a better learning-tools and it may improve their ability to solve the problems. In correlating with it, the learning-tools in tri-gonometry using the PBM model is 
not used widely yet. Therefore, this study is interested with developing it more under a learning-tools with a problem based learning-model (PBM).

\section{Method}

This study is a development research, with Model 4-D Thiagarajan.

\subsection{The Subject And Object Of Research}

The subject of this research are all students Grade X-2 and X-3 SMA Negeri 1 Kualuh Selatan. The object involved the learning-tools oriented learning problem based to develop.

\subsection{How to Develop the Learning-tools}

The learning-tools in to develop as in this study covering: RPP (the Draft of Learning, Books of Teacher (BG), Books of Student (BS), Paper of activity (LKS), instrument test of ability to solve the problem and questionnaire of self-study. Thiagarajan, Semmel, and Semmel with 4-D comprising of four stages of development either define, design,Iand disseminate. The summary of modified 4-D model is presented on figure 1 as follow.

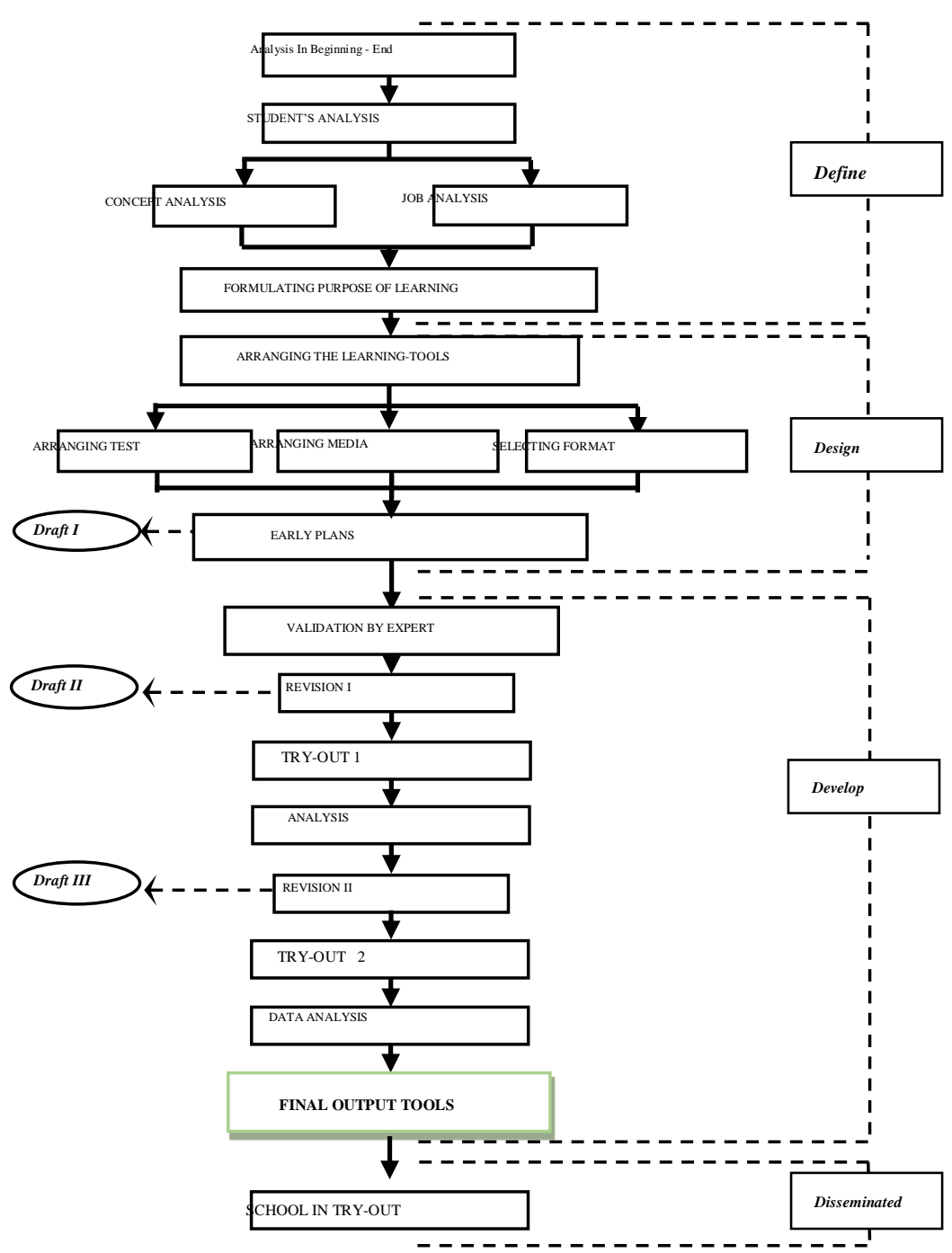


Figure 1: Flow-chart in Development Learning-tools Model 4-D (Modified from Trianto, 2011)

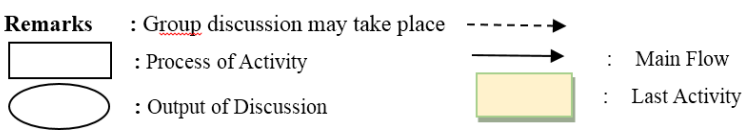

\subsection{Instrument and Data Analysis Technique}

The instrument in collecting the data in this study comprising of Firstly, validity of learning-tools using validity sheet of tools. Secondly, the learning-tools itself is practical with (1) sheet available on teacher against practical product, used to assess the practical point of RPP, book of teacher, book of student, LKS, test of ability, and questionnaire; (2) sheet of assessment to the ability of solving problem, and questionnaire of self-study; (3) sheet of observation conducting the learning used as guidance to observer in monitoring the course of mathematics with PBM model.

Thirdly, instrument of assessment to effectiveness of product consist of (1) test ability of solving problem, used to measure ability in solving problem by student; (2) sheet of observation of activity on student, used to gain data of activities; (3) sheet of their respond use to get data of students' respond.

In analyzing the data, used a descriptive statistic analysis based on average score of each learning-tools that has been validated, done it based on any correction, with suggestions given.

Further, in order to assure practically existed learning-tools, viewed from :

a. Teacher's assessment against practical learning-tools as developed can be done in classroom fulfilling minimal "easy to execute" criterion.

b. Students' view adjust that the learning-tools as developed should be easy adopted in course there fulfilling minimal "easy to execute" criterion.

c. In administering the learning-tools as developed should be run minimal in "good" category. Thus, in order to see effectiveness of the learning-tools, viewed from :

a. Full-study done by student classically is analyzed under considering for all students categorized completed if the student individually get achieved score $\geq 2.67$, whereas for any learning shall be noted completed classically if it achieved $85 \%$ students joint to the test achieving the score. To have note completed the equal is as follow

$$
\text { PKK }=\frac{\text { Students Completed }}{\text { TotalStudent involved }} \quad x 100
$$

b. The students activity is analyzed there even describe out the result of activities during doing studying. To find average frequency and average percentage of time to use, the students should follow the stages below :

1. Make frequency of each category of activity in one meeting.

2. To take average percentage of frequency in each category of activity by dividing average frequency for each category of activity with amount frequency of monitoring on each meeting.

c. The response of student should be analyzed by assessment percentage amount of students show positive response on each category as required, under a Borich formula (Herman, 2012:5).

$P R S=\frac{\sum A}{\sum B} \times 100 \%$

Remarks : 
$P R S$ : Percentage numbers of students respond positively.

$\sum A$ : Proportion of student take it

$\sum B:$ Total students (respond)

The respond is noted effective if the numbers of student respond it higher or similar to $80 \%$ of amount subject to research on each test. Still, the process given by student is seen by conformity of students' respond with the indicator of capability to solve the problem and its mathematics communication.

\section{Results}

\subsection{Description Of Stages In Development Of Learning-Tools Problem Based}

In developing the learning-tools is done using a 4-D model comprising of four stages, they are to define, design, develop, and disseminate. In details how to develop them, is mentioned as following :

a. To define Stage

1) Early Analysis of end

In field indicated that for longer the teachers have not the learning-tools properly, covering the Learning execution plan (RPP) as used perhaps not the description of learning process as executed, it shall be copy format from other teacher, since the teacher in this case never plan own self about RPP, not use LKS as supportive, and hand books used not contain any questions helping the student in improving ability to solve problem and to self-study.

2) Analysis of Student

By cognitive, student grade X-2 and Grade X-3 SMA Negeri1 Kualuh Selatan have capable to think on a formal operational. Piaget stated out on such aged, student SMA level have approached a maximal intellectual efficiency, but on shortage experiences shall limit their knowledge and capability to use what he/she knows. In addition, by interview to Head of School and teachers board school indicated that all the class-room run in similar ability (homogeny).

3) Analysis on concept

Analysis on concept aimed at identifying, mention, and arrange systematically the concepts student shall learn about mainly trigonometric become concept mapping. This concept map further is suited to the learning problem based. The concept map to produce then is put on Book of students (BS) and books of teacher (BG).

4) An Analysis of Duties

The analysis of duties covering a general works and special works. The general works refers to a core competency in curriculum 2003, while specific duties refers to a basic competency and indicator achieving the performance conformed with analysis of material in this case with material is going to improve.

5) Formulate the Purpose of Learning

Specification the purpose of learning is noted there disseminating indicator of achieving the performance more specifically bases analysis of concept and analysis of duties about main topic of trigonometric.

b. To Design

1) Arranging the test and questionnaire

The test in use are test of ability solving problem on mathematics by description. For the questionnaire containing statement to find self-study by student. 
2) Finding Media and Tools

Media in use to this research such as tools simplify the calculation. Other media in use such as illustration figures to simplify student correlate trigonometric with daily life and experiences.

3) By Format

Choosing format on the learning-tools is referred to principle, characteristic and steps in PBM model. Whereas format of book by teacher, book on student and LKS is made colorful and as attractive as possible.

4) Early Design

On this stage produce RPP for 4 sessions, students' book, teacher's book, LKS on each session, test of ability solving problem, alternative for solution and score of point each question and questionnaire about self-study, for this design is known Draft I.

c. To Develop

The result from stage define and design may produce early plan for a learning-tools either known draft I. Following finished the learning-tools problem based in plan by draft I, go to test of validity over expert review and field test.

1) Result of Validation by expert

Before field test, the learning-tools and instrument, need firstly to validate the learningtools and the instruments to those five validation-officials. By the result, then obtain criterion learning-tools and instruments to develop under "valid" and can be used by a bit revision. Further, instrument of research namely test of ability for solving and questionnaire for selfstudy should be tested in class-room outside sample, then do validity test and reliability.

2) Test I

Following fulfilling criterion valid as develop the learning-tools, then to all learningtools is known draft II. Format of this draft II is tested on the research area such as they test I done on Grade X-2. The result of data analysis in test-I is a learning-tools that has been developed having fulfilled criterion to valid and practical, but not fulfilled be effective due to found indicator be unachievable under completing to full classic to develop the problem $70.59 \%$. The result of full completing classically solving the problem on test I as well as the result of questionnaire in self-study can be seen on Table 1 and 2. 
Table 1: Classical Completing Rate in Ability Solving the Problem by student As On Test I

\begin{tabular}{|c|c|c|c|}
\hline Category & Frequency & $\begin{array}{c}\text { Percentage } \\
(\%)\end{array}$ & $\begin{array}{c}\text { Averag } \\
\text { e }\end{array}$ \\
\hline $\begin{array}{l}\text { Complete } \\
\text { d }\end{array}$ & 24 & 70,59 & \multirow[b]{2}{*}{2,753} \\
\hline $\begin{array}{l}\text { Not } \\
\text { Complete } \\
\text { d }\end{array}$ & 10 & 29,41 & \\
\hline Total & 34 & 100 & \\
\hline
\end{tabular}

Table 2. Result by Questionnaire in Self-study as Test

\begin{tabular}{|l|c|c|c|}
\hline Category & Frequency & $\begin{array}{c}\text { Percentage } \\
(\mathbf{\%})\end{array}$ & $\begin{array}{c}\text { Averag } \\
\text { e }\end{array}$ \\
\cline { 1 - 3 } Very High & 5 & 14,71 & \multirow{2}{*}{$\mathbf{4 7 , 8 8}$} \\
\cline { 1 - 3 } High & 9 & 26,47 & \\
\cline { 1 - 3 } Low & 17 & 50 & \\
\cline { 1 - 3 } Very Low & 3 & 8,82 & \\
\cline { 1 - 3 } Total & $\mathbf{3 4}$ & $\mathbf{1 0 0}$ & \multicolumn{1}{|c}{} \\
\cline { 1 - 3 } & & &
\end{tabular}

From Table 1 can be seen that average ability in solving problem on Test I is 2.753 by maximum rate 4.0. Percentage of student do completed is $70.59 \%$. This percentage is obtained by dividing frequency of student do completed noted 22 student out 34 x $100 \%$. Refers to criterion of assessment, this percentage not fulfill classical completed as decided namely $\geq 85 \%$. Whereas, result of questionnaire in self-study as obtained as showed table 2 indicated that average self-study of student seen 47.88 of maximum rate 72 . Percentage of self-study with highly category is $14.71 \%$. So, it is necessary to revise on Draft II upon some component of learning-tools as developed.

3) Test II

Following done a Test I on Draft II, then make correction to produce a learning-tools fulfilling an effective require. The result of revision on Test I producing draft III to be tested on further class namely on Grade X-3. This Test-II is done 4 times session refers to the plan on learning (RPP) that has been improved. The test-II was done to assess the effectiveness of learning-tools (draft III). Besidecorrecting to test I, this test II is also done to see improvement ability of solving problem and self-study by student. In whole, the classical completed rate of ability in solving problem by student on test II can be seen on Table 3 and the result of selfstudy by student is on Table 4 .

Table 3. Classical Completed Rate ability Solving the Problem by Student on Test II

\begin{tabular}{|c|c|c|c|}
\hline Category & Frequency & $\begin{array}{c}\text { Percentage } \\
(\%)\end{array}$ & Average \\
\hline Completed & 30 & 85,71 & \multirow[b]{2}{*}{3,04} \\
\hline $\begin{array}{l}\text { Not } \\
\text { Completed }\end{array}$ & 5 & 14,29 & \\
\hline Total & 35 & 100 & \\
\hline
\end{tabular}


Table 4. The result Questionnaire of Self-study on Test II

\begin{tabular}{|l|c|c|c|}
\hline Category & Frequency & $\begin{array}{c}\text { Percentage } \\
(\mathbf{\%})\end{array}$ & Average \\
\hline Very High & 5 & 14,29 & \\
\cline { 1 - 3 } High & 15 & 42,86 & \multirow{2}{*}{$\mathbf{4 9 , 8 2}$} \\
\cline { 1 - 3 } Low & 9 & 25,71 & \\
\cline { 1 - 3 } Very Low & 6 & 17,14 & \\
\cline { 1 - 3 } Total & 35 & 100 & \multicolumn{1}{|c}{100} \\
\cline { 1 - 3 } & &
\end{tabular}

Based on data on Table 3, seen that average ability solving problem on Test II noted 3.05 of maximum rate 4.0 . Percentage of student completed is $85.71 \%$. Refers to criterion of assessment, this percentage has fulfilled already classical completed decided on $\geq 85 \%$. It is concluded that classical completed criterion is fulfilled. Further, on students' activity is obtained that on test-II all students' activity ranged on ideal time as determined with tolerated limit 5\%. On students' response is obtained the student responded positively on the learningtools oriented learning problem based. Concluded that the learning-tools problem based as developed on test-II as the revision of test-I has fulfilled already the learning-tools in practical and effective.

d. Disseminate

Disseminating of learning-tools problem based as developed in this case done under providing a learning-tools over forum MGMP in school where the test to use later.

\subsection{Improvement Ability Solving Problem and Self-study of Students Using a Learning- tools Oriented Learning Problem Based as Developed}

Bases to the result of analysis improvement ability solving problem by students on test-I and II indicated that average ability in solving problem on test I is 2.75 , whereas on test II is 3.04. Percentage of student completed it on test I is $70.59 \%$ and not completed $29.41 \%$. Refers to the assessment criterion, percentage in completed as this $70.59 \%$ not fulfilled classical completed as decided namely $\geq 85 \%$. While on test II, percentage of student completed full is $85.71 \%$ and not completed $14.29 \%$. Percentage completed with this $85.71 \%$ has fulfilled already classical completed as decided.

Whereas result of analysis improvement ability in self-study obtained that average selfstudy by student on test-I is 47.88 , whereas on test II is $49.82 \%$. This a verage is obtained from dividing total score in all students with numbers of student. Percentage of students on test-I with category self-study with very high is $14.71 \%$, with high $26.47 \%$, low $50 \%$ and very low $8.82 \%$. Percentage students on category very high is $14.71 \%$ obtained from numbers of student as included into category with self-study with high rate (in this case 5) divided numbers of student namely 34 and x 100\%. Whereby, percentage of student on test II with category self-study is very high $14.29 \%$, high $42.86 \%$, low $25.71 \%$ and very low $17.14 \%$ respectively.

Representation category self-study on student obtained on test II got increased on high category. Having rise up high $16.3 \%$, and this also indicated that percentage self-study of highest is on test I ranged on low category, whereas on test-II ranged on category high. The result of research showed ability solving problem and self-study using the learning-tools as 
developed got rising. Concluded that the learning-tools problem based influenced to a rising ability solving problem and self-study on students.

\section{Discussion}

Bases to validation, the learning-tools has been done valid by validator. In essentially, the result of validation RPP, comprising of four sessions indicated that component in RPP of category such as quite good, good, and very good with average total 4.60. Beside RPP, the result of validation on books of student also indicated that components in that books got such as goo and very good of average totally 4.45 . Further, validation on books of teacher also indicated that components in that book got such as quite good, good, and very good with average total 4.47. The result of validation LKS also got such as category good and very good with average total 4.52. This also indicated that components in LKS is categorized good.

Further, validation of test ability solving problem is available of category not valid, valid still upon validity of content, can and be acceptable upon language and to write the questions and to recommend without any revision, a small revision, and high revision. Following done revision, the questions that has been improved fulfilling already criterion valid and is acceptable to measure ability of solving problem as on field test. It is also done on questionnaire of self-study, the result of validation indicated that components such questionnaire as self-study also ranged on category of valid, quite valid and one point statement is not valid upon validity of content; can and be acceptable upon the language and how to write; and to recommend without any revision and small revision. Following done revision, another 35 points statement as developed has fulfilled already criterion valid and be acceptable.

Bases to field test, concluded that product expandable has fulfilled criterion practical. Upon practical product can be seen from the data of assessment on teacher and student upon practical of product, and observation to realization of learning mathematics with PBM model using product as expanded.

Average score of assessment of teacher against practical of product is available on category "very easy to execute". Assessment by teacher, percentage of student make adjust on product is on category minimal "easy to use" is $100 \%$ so it can be noted that product as expanded practical to use.

The learning on mathematics is done refers to model as used on RPP, namely PBM model. Average percentage done on mathematics with PBM model used product as expanded is $91.67 \%$, it means the implementation has achieved minimal limit noted product as expanded practical to use in mathematics.

In generally, product expanded fulfilled the practical criterion if existed consistency between adjust by teacher and student with condition applied in field. Bases to test I and II, the learning-tools oriented learning problem based as expanded has fulfilled category effective if viewed from : (1) completed learning students classical; (2) activity of student within time tolerated as decided; (3 ) student respond it positively on the learning-tools component problem based.

Average ability solving problem by student in test II is 3.04 with percentage completed is $85.71 \%$, this point is seen criterion classical completed is fulfilled.

By monitoring, students' activity seen that it is on criterion limited learning effective as noted on Chapter III. On test I, aspect ask questions achieved $14.47 \%$. Even it is still in 
criterion as decided, tending to ask their teacher not to other student in the same group. On test II of this aspect increased up to 15.51. Even through, on test-II the students has questioned fellow student.

Many questions asked to teacher but it correlated the teacher adjusted to condition of student can not fulfilled. This outcome is noted as one of references to revise books of student and LKS. One of points to improve is the question of point $d$ on LKS is detailed specifically and some formulas required in solving, but student do not remember need to add on book. In order to adjust the activities, alternative to repair such as : (a) teacher lead students completed question point $d$ and try using the outcome obtained in finding one of points known or give other solution to respond the problem given, (b) adding guidance and explanation details on the problem available found on book. Following repair, the activities of students on test II available on a tolerated limit decided.

Additionally, analysis to students' respond related with their feeling agains aspect of component of learning-tools namely their opinion upon the material, books of student, LKS and atmosphere of learning is lower than aspect of other tools. Bases to comments and interview done over to students giving negative respond, their reasonable is their refusal on group study.

Further, analysis to students' respond is related renewal component of tools either books of student, LKS, material and atmosphere achieved $80 \%$. Although achieved already $80 \%$, some comments of student on questionnaire shall be consideration to revise tools before test II. One of comments by student seen about atmosphere of learning in noises with group-study.

By aspect of enthusiasm students to attend the session, mostly students respond it positively above $90 \%$, it means students interested with involving in further learning activity. Aspect of clearly language used on books and LKS has achieved 90\% already, but regarding words, sentences or instruction questioned by student during learning is noted referred repairing of language. The words or sentences not understood well added available explanation or replaced in more simple one and solution to problem in book is added conclusion or important concept need to understand. Aspect of interesting upon books and LKS is also achieved $80 \%$.

By repairing done as on test II, aspects of students' respond either on feelings of student against the tools, renewal on component of tools and clearly of language on books and LKS is persistent in category good. So, the final tools resulted has fulfilled criterion effective.

According to a research by Sinaga (2007) indicated that students res pond positively to the learning-tools bases problem focused on Batak cultures. By exposes of research showed that concluding the components of learning-tools problem based as expanded contributed positively to students' respond.

By having improved ability solving problem and by self-study using the learning-tools problem based as improved is seen properly, bases to average on both tests, found improvement ability of 0.29 point with $15.12 \%$ having improved completed, still improved in self-study of 1.94 point, by category, is found improvement with high category.

The result of research as above is relevant to Smith (Amir, 2010:27) stated out that various dimension and profitable of learning problem based for students such as to improve their capability to solve problem, easier to remember, improved understanding up, improved knowledge relevant to daily practicing, also to enrich their ability on leadership and cooperation, competency, and motivation.

This point is supported in outcome by Susanti (2015) got product with learning-tools problem based as expanded improving their ability solving problem and ability to connect 
mathematics. It is concluded that the learning-tools problem based possibly to improve ability solving problem.

\section{Conclusion}

By the result of analysis and understanding to this problem, can be taken conclusion as following :

1. Validity of learning-tools as expanded including into category valid with average rate validity RPP in 4.60, books of student in 4.45, books of teacher in 4.47, LKS rate of 4.52, test of ability solving problem in category sufficienet valid and valid, as well as point of statement questionnaire with self-study as student.

2. The product as the learning-tools in mathematics for SMA Grade X with PBM model that has been tested and got into criterion practical. This bases to the result of research of students indicated that product as tested got already fulfilling criterion practical. The result by teacher indicated that product as tested got already criterion "very easy to conduct". The data was supported by data results of observation conducting learning mathematics with PBM model with average percentage applied achieved 91.67\%.

3. Effectiveness of learning-tools fulfilling criterion effective, they are : (a) achieving completed studying with percentage of classical completed in $85.71 \%$; (b) activity done by students fulfilled criterion of ideal time tolerated as decided; (c) respond of students over learning-tools is in category good.

4. Average improved ability solving problem by students on test I into test II is 0.29 point and its classical completed improved in $15.12 \%$.

Average improved self-study by students as in test I into test II is 1.94 point. In category, seemly improved on category high on test II.

\section{References}

[1]Amir, M.T. 2010. Inovasi Pendidikan Melalui Problem Based Learning. Jakarta: Kencana Prenada Media Group.

[2]Fauzi, A. 2011. Peningkatan Kemampuan Koneksi Matematis dan Kemandirian Belajar Siswa dengan Pendekatan Pembelajaran Metakognitif di Sekolah Menengah Pertama. Proceedings of International Seminar and the Fourth National Conference on Mathematics Education "Building the Nation Character through Humanistic Mathematics Education". Department of Mathematics Education, Yogyakarta State University, Yogyakarta, July 21-23: $109-122$.

[3]Herman. 2012. Pengembangan Perangkat Pembelajaran Model Pengajaran Langsung Untuk Mengajarkan Materi Kesetimbangan Benda Tegar. Jurnal Sains dan Pendidikan Fisika, 8 (1): $1-11$.

[4]Hudojo, H. 1988. Mengajar Belajar Matematika. Jakarta: Departemen Pendidikan Dan Kebudayaan P2LPTK Jakarta.

NCTM. 2010. Why is Teaching with Problem Solving Important to Students Learning?. Problem Solving Reasearch Brief.

[5]Polya, G. 1973. How To Solve $\left(2^{\text {nd }}\right.$ Ed. Princeton University Press.

[6]Purnamasari, Y. 2014. Pengaruh Model Pembelajaran Kooperatif Tipe TGT terhadap Kemandirian Belajar dan Peningkatan Kemampuan Penalaran dan Koneksi Matematik Peserta Didik SMPN 1 Kota Tasikmalaya. Jurnal Pendidikan dan Keguruan, 1 (1): 1 - 11.

[7]Ruseffendi, E.T. (1991). Pengantar kepada Membantu Guru Mengembangkan Kompetensinya dalam Pengajaran Matematika untuk Meningkatkan CBSA. Bandung: Tarsito. 
[8]Siagian Pargaulan, Simanjuntak Erlinawaty, and Samosir Katrina. Prototype Teaching Mathematics in Improving Critical Thinking Ability of Senior High School Students. International Journal of Innovation in Science and Mathematics. Vol. 5, Issue 2 ISSN (online). $2347-9051$.

[9]Sinaga, B. 2007. Pengembangan Model Pembelajaran Matematika Berdasarkan Masalah Berbasis Budaya Batak (PBMB3). Disertasi tidak diterbitkan. Surabaya: PPs Unnes.

[10]Sulistyaningsih. 2012. Model Pembelajaran Kooperatif Tipe Circ Dengan Pendekatan Konstruktivisme Untuk Meningkatkan Kemampuan Koneksi Matematik. Unnes Journal of Mathematics Education Research. 1(2): 2252 - 6455.

[11]Susanti, N. 2015. Pengembangan Perangkat Pembelajaran Berbasis Model Pembelajaran Berdasarkan Masalah Untuk Meningkatkan Kemampuan Pemecahan Masalah Dan Kemampuan Koneksi Matematis Siswa SMP Negeri 27 Medan. Tesis tidak diterbitkan. Medan: Program Pascasarjana UNIMED.

[12]Thiagarajan, S. dkk. 1974. Instructional development for Training Teachers of Exceptional Children A Sourcebook. Minnesota: National Center For Improvement of Educational System.

[13]Trianto. 2011. Mendesain Model Pembelajaran Inovatif-Progresif: Konsep, Landasan dan Implementasinya pada Kurikulum Tingkat Satuan Pendidikan (KTSP). Jakarta: Kencana.

Undang-Undang Republik Indonesia Nomor 14 Tahun 2005 tentang Guru dan Dosen. 2007. Jakarta : Visimedia.

[14]Wardhani, S \& Rumiati. 2011. Instrumen Penilaian Hasil Belajar Matematika SMP:Beajar dari PISA dan TIMSS. Yogyakarta: PPPPTK. 